\title{
Gender-Differences in Mice Hypericin Plasma Levels Upon Long-Term Hypericum Administration
}

\author{
Beatrice Mihaela Radu*, ${ }^{*}$ Valentina Anuta ${ }^{2,3}$ and Gheorghe Stoian ${ }^{4}$
}

\begin{abstract}
${ }^{I}$ Department of Animal Physiology and Biophysics, Faculty of Biology, University of Bucharest, 91-95, Splaiul Independentei, 050095, Bucharest, Romania; ${ }^{2}$ Biopharmacy \& Pharmacol RES S.A., 23, Pitar Mos st, Bucharest, Romania; ${ }^{3}$ Faculty of Pharmaceutics, 'Carol Davila' University of Medicine and Pharmaceutics, 6, Traian Vuia st, Bucharest, Romania; ${ }^{4}$ Department of Biochemistry and Molecular Biology, Faculty of Biology, University of Bucharest, 91-95, Splaiul Independentei, 050095, Bucharest, Romania
\end{abstract}

\begin{abstract}
Hypericum perforatum (St John's wort) is a well known medicinal plant used in many pharmaceutical formulations and its main active compound is hypericin. The purpose of our study was to examine the plasma level of hypericin upon long term mice treatment with Hyperici herba extract. A reversible hyperthermia was recorded upon 2 hours of the extract administration, both in males and females. Hypericin plasma levels in mice were evaluated by HPLC analysis. In 1-month old mice, no significant gender differences in the hypericin plasma level were recorded. By contrast, at the age of 3 -months, hypericin plasma levels are significantly more elevated in females $(93 \pm 7 \mathrm{ng} / \mathrm{ml} ; \mathrm{n}=8, \mathrm{p}<0.05)$ than in males $(32 \pm 3 \mathrm{ng} / \mathrm{ml} ; \mathrm{n}=9)$. In conclusion, gender specific precautions must be considered when Hypericum is prescribed in human patients.
\end{abstract}

Keywords: Hyperici herba, hypericin, body temperature, plasma levels, gender.

St John's wort (Hypericum perforatum) is an herbal remedy that is widely used in the treatment of depression. $H y$ perici herba is the aerial part collected during the flowering period from the well-known herb Hypericum perforatum. Recent clinical data have demonstrated that Hypericum perforatum extracts interfere with the action of various drugs and possibly also with combined oral contraceptives.

Co-administration of Hypericum and oral contraceptives may increase unintended pregnancy risk [1], seven cases being reported by the United Kingdom authorities [2]. The Medical Products Agency from Sweden received eight reports of intermenstrual bleedings and one of changed menstrual bleeding from manufacturers of St John's wort products [3]; in Switzerland have been reported similar clinical cases [1].

At the molecular level, it was proven that long-term human administration of St John's wort may result in diminished clinical effectiveness or increased dosage requirements for all CYP 3A4 substrates [4]. In addition, short term administration does not alter most of the circulating androgens, except for the 5 $\alpha$-reduced androgens [5].

Daily treatment with either Hypericum extract (or hypericin alone) for 14 days significantly decreased plasma ACTH and corticosterone levels, but does not affect the plasma prolactin or LH levels [6]. Ze117 extract (low hyperforin content), does not interact with the pharmacokinetics of the hormonal components of the low-dose oral contraceptive $[3,7]$.

*Address correspondence to this author at the Department of Animal Physiology and Biophysics, Faculty of Biology, University of Bucharest, 91-95, Splaiul Independentei, 050095, Bucharest, Romania; Tel: + 40213181573; Fax: +40213181573; E-mail: beatrice_macri@yahoo.com
Our interest was to evaluate the possible gender differences in the body temperature and the hypericin plasma level upon long term treatment of RAP mice with Hyperici herba extract.

The procedures and protocol design are in accordance with the ethical guidelines and regulations of the European Union. In this study we have used 1, respectively 3 months old RAP mice of both sexes. Each group was subdivided into a control subgroup and a test subgroup, treated daily for a month. The control subgroup received hydro-alcoholic mixture (5\% alcohol) and the test group received Hyperici herba hydro-alcoholic extract. The body weight was monitored at specific intervals $0,1,2,4$, and 12 weeks.

The Hyperici Herba extract was provided by Bionorica Company (Germany) and their HPLC analysis indicates a content of $0.19 \%$ hypericin, $0.25 \%$ pseudohypericin and $3.4 \%$ hyperforin. During one month oral administration, a daily total dose of $1500 \mathrm{mg} / \mathrm{kg}$ Hyperici was administered in 3 hits. Solubilisation was done in a mixture of 5\% ethylic alcohol, $2 \%$ sucrose and deionized water (MilliQ). In order to increase the solubility, the extract was sonicated for 2 hours with a Soniprep 150 (Sanyo, Gallenkamp PLC, UK). In order to reduce photodamage effects, the whole solution was prepared at the beginning of the experiment, and maintained in dark conditions at $2-4{ }^{\circ} \mathrm{C}$. The animals were sacrified at 24 hours after the last oral dose.

The body temperature was measured with a digital thermometer (LCD Digital, Prima Long) intra-anal at 0, 1, 2, 3 and 4-hours after the dosage administration. In the control group, the animals received daily a mixture of 5\% ethylic alcohol, 2\% sucrose and deionized water (MilliQ), and the body temperature was also monitored in order to substract from the alcohol influence. 


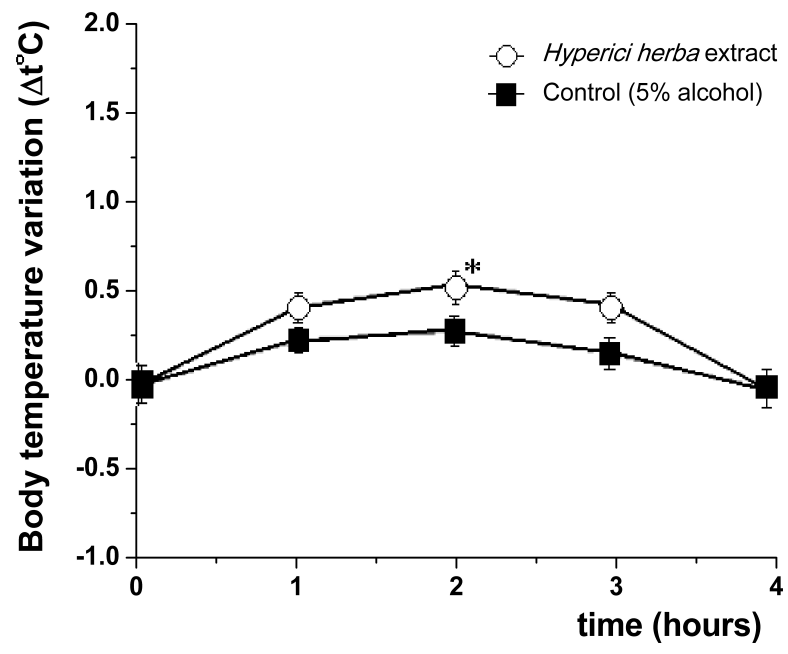

Fig. (1). Mean body temperature variation determined by Hyperici herba administration.

The retro-orbital blood sample prelevation was done at 0 , 2, 4, 8 and 12 weeks. The samples were prelevated in EDTA treated tubes and centrifuged (6200 x g, $10 \mathrm{~min})$. Plasma was transferred into other tubes and preserved in dark conditions at $-20{ }^{\circ} \mathrm{C}$ until the HPLC analysis of the samples.

For the reverse phase chromatography, we have chosen a Kromasil 100-5C18 column (150 x 4.6 mm, Eka Chemicals A.B., Separation Products, Sweden). The mobile phase was mixed (Jasco LG-980-02) for a gradient of acetate buffer : acetonitril $=25: 75(\mathrm{v} / \mathrm{v})$. The acetate buffer contains $1.68 \times 10^{-3} \mathrm{mg} / \mathrm{ml} \mathrm{CH} \mathrm{COONH}_{4}$ and $0.04 \%$ acetic acid $(\mathrm{pH}=5.0)$. The pump flow (Jasco PU-980), was maintained at $1.2 \mathrm{ml} / \mathrm{min}$, and the temperature of the column at $45^{\circ} \mathrm{C}$. In order to prepare the samples, $1 \mathrm{ml}$ of plasma was mixed with $0.4 \mathrm{ml}$ DMSO and $0.15 \mathrm{ml}$ acetonitril, and shaken for $30 \mathrm{~s}$. Then, $2.5 \mathrm{ml}$ ethyl acetate : n-hexane (70:30, w/w) was added, and the samples were shaken for another $20 \mathrm{~min}$. The organic superior layer was suctioned, and the residual layer was twice submitted to the same procedure. The organic layers resulted from the $1^{\text {st }}$ and $2^{\text {nd }}$ extraction were mixed and evaporated in nitrogen conditions at $40{ }^{\circ} \mathrm{C}$. Resuspension was done in $175 \mu \mathrm{l}$ mobile phase, followed by $15 \mathrm{~min}$ sonication. $100 \mu \mathrm{l}$ was automatically injected (Waters 712 WISP, Millipore Corporation, USA) into the HPLC system. Hypericin was detected at $\lambda_{\text {ex }}=315 \mathrm{~nm}, \lambda_{\text {em }}=590 \mathrm{~nm}$ (Spectra SYSTEM FL2000, Thermo separation). HPLC analysis of the hypericin indicated a retention time of $8.05 \pm 0.20 \mathrm{~min}$ and the limit of detection was $5 \mathrm{ng} / \mathrm{ml}$. The method of extraction was calibrated in the therapeutic range concentration $(0.05-0.1 \mu \mathrm{g} / \mathrm{ml})$ (see Fig. 2 inset). Statistics was done in Prism by Student t-test $(\mathrm{p}<0.05)$.

In our study, a maximal hyperthermia phenomenon was recorded 2 hours after the Hyperici herba administration. A general profile of the body temperature for all the tested animals is represented in Fig. (1). From mean temperature profile one can notice the reversible character of the process. In should be mentioned that, two cases of hypothermia were reported in the 3-month old male group.

In each subgroup it was done the temperature profile and data are collected in Table $\mathbf{1 .}$

In our experiment, all environmental stress factors were eliminated, in order to avoid their influence on body temperature.

Similar data were reported for small Hypericum dietary doses $(250$ or $500 \mathrm{mg} / \mathrm{kg}$, [8]), but only for NMRI males. Hyperthemia doesn't seem be dependent of the mice genotype (i.e. NMRI mice and RAP mice). Behavioral tests (i.e. open field tests) indicated that Hypericum perforatum extract $(250$ or $500 \mathrm{mg} / \mathrm{kg})$ components reduced the temperature difference recorded in stress-induced hyperthermia for BL6/C57J mice [9]; no effect was detected for higher (750 or $1000 \mathrm{mg} / \mathrm{kg}$ ) or lower $(125 \mathrm{mg} / \mathrm{kg})$ doses.

In rats, the Hypericum-induced hyperthermia was also recorded [8]. In humans, an extreme clinical case was reported for a 22-year man that had fever and ulceration of the oral mucosa upon a daily treatment with $1000 \mathrm{mg} /$ day flowering herbs Hypericum [10].

Blood samples were prelevated from the males and females that underwent the body temperature monitoring, and the HPLC analysis for hypericin content evaluation was done.

At 1-month age, no significant gender differences in the plasma level were recorded $(22 \pm 2 \mathrm{ng} / \mathrm{ml}, \mathrm{n}=8$, for males compared to $17 \pm 1 \mathrm{ng} / \mathrm{ml}, \mathrm{n}=8$, for females, $\mathrm{p}=0.11)$. By contrast, at 3-month age, hypericin plasma levels for females $(93 \pm 7 \mathrm{ng} / \mathrm{ml} ; \mathrm{n}=8)$ is significantly more elevated than for males $(32 \pm 3 \mathrm{ng} / \mathrm{ml} ; \mathrm{n}=9, \mathrm{p}<0.05)$ (Fig. 2).

The drug safety of Hypericum might be questionable. In comedication, the transient temperature fluctuations induced by its oral administration can determine a drug-enhanced absorption. In addition, the plasma gender differences resulted from our study could be important when Hypericum extract is co-administered with oral contraceptives and other

Table 1. Body Temperature in Control and Hyperici herba Treated Subgroups

\begin{tabular}{|c|c|c|c|c|c|}
\hline \multirow{3}{*}{$\begin{array}{l}\text { Body temperature } \\
\left({ }^{\circ} \mathrm{C}\right)\end{array}$} & & \multicolumn{2}{|c|}{ Males } & \multicolumn{2}{|c|}{ Females } \\
\hline & Control subgroup & $\begin{array}{c}36.90 \pm 0.20 \\
\mathrm{n}=8\end{array}$ & $\begin{array}{c}36.98 \pm 0.93 \\
\mathrm{n}=9\end{array}$ & $\begin{array}{c}36.93 \pm 0.61 \\
\mathrm{n}=10\end{array}$ & $\begin{array}{c}37.55 \pm 0.55 \\
\mathrm{n}=8\end{array}$ \\
\hline & $\begin{array}{l}\text { Hyperici herba } \\
\text { treated subgroup }\end{array}$ & $\begin{array}{c}39.13 \pm 0.24 \\
\mathrm{n}=8, \mathrm{p}<0.01\end{array}$ & $\begin{array}{c}38.41 \pm 1.07 \\
\mathrm{n}=9, \mathrm{p}<0.05\end{array}$ & $\begin{array}{c}38.98 \pm 0.38 \\
\mathrm{n}=10, \mathrm{p}<0.01\end{array}$ & $\begin{array}{c}38.93 \pm 0.98 \\
\mathrm{n}=8, \mathrm{p}<0.01\end{array}$ \\
\hline
\end{tabular}




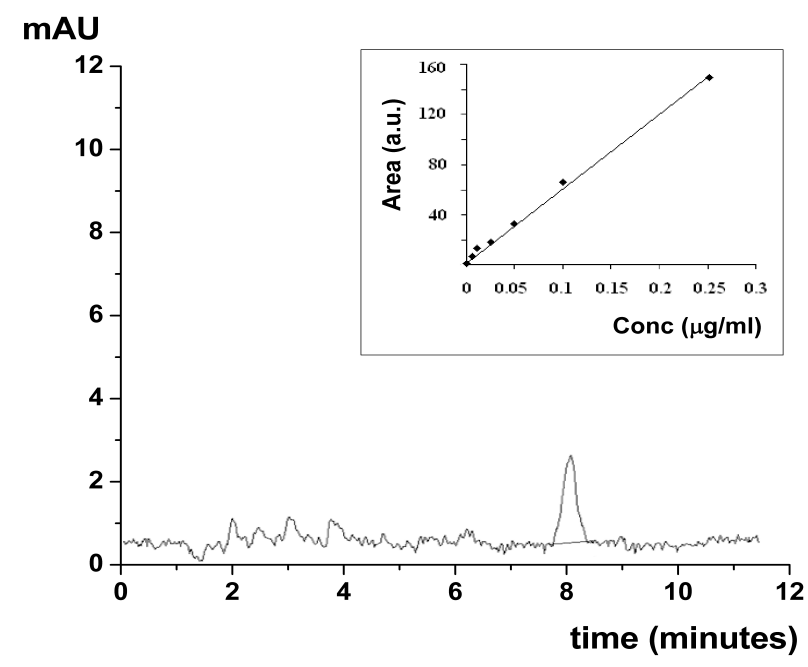

Fig. (2). HPLC analysis of plasma samples. Reverse phase chromatography for a sample that contains $90 \mathrm{ng} / \mathrm{ml}$ hypericin. Inset. Linearity of the method with a limit of detection equal to $5 \mathrm{ng} / \mathrm{ml}$ ).

CYP 3A4 substrates. Supplementary blood test should be done in patients that receive different phytopharmaceuticals containing Hypericum formulations.

\section{ACKNOWLEDGMENTS}

The study was financed by the grant CEEX 6109/2005 from the Romanian Ministry of Research. Many thanks for the kind gift from Dr. Gudrun Werner from Bionorica Company, Germany. We are grateful to Dr. E. Dragan (veterinary) and all the personal from the animal housing facility of the Institute of Cellular Biology and Pathology 'Nicolae Simionescu'. All the gratitude to the staff members of Biophar- macy and Pharmacol Res. S.A. who helped us with the HPLC protocol.

\section{REFERENCES}

[1] Pfrunder, A.; Schiesser, M.; Gerber, S.; Haschke, M.; Bitzer, J.; Drewe, J. Interaction of St John's wort with low-dose oral contraceptive therapy: a randomized controlled trial. Br. J. Clin. Pharmacol., 2003, 56(6), 683-690.

[2] http://news.bbc.co.uk/hi/english/health/newsid_1802000/ 1802943.stm

[3] Yue, Q.Y.; Bergquist, C.; Gerdén, B. Safety of St John's wort (Hypericum perforatum). Lancet, 2000, 355(9203), 576-577.

[4] Markowitz, J.S.; Donovan, J.L.; Devane, C.L.; Taylor, R.M.; Ruan, Y.; Wang, J.S.; Chavin, K.D. Effect of St John's wort on drug metabolism by induction of cytochrome P450 3A4 enzyme. JAMA, 2003, 290(11), 1500-1504

[5] Donovan, J.L.; Devane, C.L.; Lewis, J.G.; Wang, J.S.; Ruan, Y. Chavin, K.D.; Markowitz, J.S. Effects of St John's wort ( $\mathrm{Hy}$ pericum perforatum $\mathrm{L}$.) extract on plasma androgen concentrations in healthy men and women: a pilot study. Phytother. Res., 2005 19(10), 901-906.

[6] Butterweck, V.; Korte, B.; Winterhoff, H. Pharmacological and endocrine effects of Hypericum perforatum and hypericin after repeated treatment. Pharmacopsychiatry, 2001, 4(Suppl 1), 2-7.

[7] Will-Shahab, L.; Bauer, S.; Kunter, U.; Roots, I.; Brattström, A. St John's wort extract (Ze 117) does not alter the pharmacokinetics of a low-dose oral contraceptive. Eur. J. Clin. Pharmacol., 2009, 65(3), 287-294.

[8] Butterweck, V.; Wall, A.; Liefländer-Wulf, U.; Winterhoff, H.; Nahrstedt, A. Effects of the total extract and fractions of $H y$ pericum perforatum in animal assays for antidepressant activity. Pharmacopsychiatry, 1997, 30(Suppl 2), 117-124.

[9] Grundmann, O.; Kelber, O.; Butterweck, V. Effects of St. John's wort extract and single constituents on stress-induced hyperthermia in mice. Planta Med., 2006, 72(15), 1366-1371.

[10] Demiroglu, Y.Z.; Yeter, T.T.; Boga, C.; Ozdogu, H.; Kizilkilic, E.; Bal, N.; Tuncer, I.; Arslan, H. Bone marrow necrosis: a rare complication of herbal treatment with Hypericum perforatum (St. John's wort). Acta Med. (Hradec Kralove), 2005, 48(2), 91-94.

(C) Radu et al.; Licensee Bentham Open.

This is an open access article licensed under the terms of the Creative Commons Attribution Non-Commercial License (http://creativecommons.org/licenses/by-nc/3.0/) which permits unrestricted, non-commercial use, distribution and reproduction in any medium, provided the work is properly cited. 